\title{
INSOMNIAC CHILDREN MATERNAL SLEEP AND MOOD IN SÃO PAULO AND BARCELONA
}

\author{
Eduardina Tenenbojm 3 , Geisa Angelis ${ }^{4}$, Sueli Rossini ${ }^{2}$, \\ Eduard Estivill', Francisco Segarra ${ }^{6}$, Rubens Reimão
}

\begin{abstract}
Objective: To evaluate sleep characteristics verifying for the presence of depressive symptoms in mothers of insomniac children living in São Paulo (Brazil) and Barcelona (Spain). Method: Forty-six mothers were evaluated, 37 from São Paulo and nine from Barcelona, their ages varying from 19 to 44, and their children; otherwise healthy but with complaints of insomnia, their age varying from three to 33 months. The mothers' sleep quality was rated by the Pittsburgh Sleep Quality Index (PSQI), and the Beck Depression Inventory (BDI). Results: $91.30 \%$ of mothers reported poor sleep by PSQI standards. Regarding signs and symptoms of depression, $69.56 \%$ of all mothers in this sample showed them. Direct correlation between São Paulo mothers PSQI and BDI was found and also between the child's age and BDI. Conclusion: The mothers' poor sleep was related to mood changes with symptoms of depression presenting similar results in both cities.
\end{abstract}

KEY WORDS: sleep, sleep disorders, child, insomnia, mood disorder.

\section{Sono e humor de mães de crianças pequenas com insônia em São Paulo e Barcelona}

Resumo - Objetivo: Avaliar a presença de sintomas depressivos em mães de crianças com insônia em São Paulo e Barcelona. Método: Quarenta e seis mães foram avaliadas, 37 de São Paulo e nove de Barcelona, suas idades variaram de 19 a 44 anos, e suas crianças, saudáveis, mas com queixa de insônia tinham idades de três a 33 meses. A mãe foi avaliada pelo Índice de Qualidade de Sono de Pittsburgh (PSQI) e pelo Índice de Depressão de Beck (IDB). Resultados: 91,30\% das mães relataram sono ruim pelo padrão do PSQI. Quanto aos sinais e sintomas de depressão, 69,56\% das mães da amostra total relatavam. Nas mães de São Paulo foi constatada correlação direta entre o PSQI e o IDB, bem como a idade da criança e o IBD. Conclusão: O sono ruim das mães se correlacionou com sinais e sintomas depressivos e os resultados foram semelhantes nas duas cidades.

PALAVRAS-CHAVE: sono, distúrbios do sono, criança, insônia, transtorno do humor.

Sleep is essential for child development in the early years of life ${ }^{1,2}$. Infant insomnia ${ }^{3}$ is defined as the difficulty infants to go through to fall asleep or a considerable number of awakenings at night. The infants' insomnia impairs the parents, depriving them of sleep. In the first months of life a gradual reduction in the hours of sleep is expected in the normal child. At this age, sleep is usually continuous during the night.

External synchronizers of the sleep and wake rhythm keep a close relation to family members behavior as to the infant's sleep ${ }^{4}$.

The objective of this study was to evaluate the sleep characteristics (quality, efficiency, subjective perception and excessive daytime sleepiness) verifying for the presence of depressive symptoms in mothers of insomniac children living in São Paulo (Brazil) and Barcelona (Spain). This is part of a larger project of the authors to evaluate sleep in children and adolescents ${ }^{5,6}$.

\section{METHOD}

Forty-six mothers were evaluated, 37 from São Paulo and nine from Barcelona, their ages varying from 19 to 44 years old, and their children; otherwise healthy but with complaints of insomnia, their ages varying from three to 33 months old. Sample allocation took place in Department of Neurology Outpatient Clinic, Hospital das Clinicas, University of São Paulo Med-

Division of Clinical Neurology, Hospital das Clinicas, University of São Paulo Medical School, São Paulo SP, Brazil: 'Pediatric Neurologist, MD, PhD, Division of Clinical Neurology, Hospital das Clinicas, University of São Paulo Medical School, São Paulo SP, Brazil (HC-USP); ${ }^{2}$ Psychologist, PhD, Division of Clinical Neurology, HC-USP; ${ }^{3}$ Pediatrician MD, Division of Clinical Neurology, HC-USP; ${ }^{4}$ Psychologist, Division of Clinical Neurology, HC-USP; ${ }^{5}$ Pediatric Neurologist, MD, PhD, Clinica del Sueño Estivill, Institut Universitari Dexeus, Barcelona, Spain; ${ }^{6}$ Psychologist, PhD, Clínica del Sueño Estivill, Institut Universitari Dexeus, Barcelona, Spain. Funding: CAPES Grant 2199/07-6.

Received 20 February 2008, received in final form 5 June 2008. Accepted 20 June 2008.

Dr. Rubens Reimão - Rua dos Bogaris 38 - 04047-020 São Paulo SP - Brasil. E-mail: reimaorubensneuro@yahoo.com 
Table 1. Sample descriptions and results of comparative tests.

\begin{tabular}{|c|c|c|c|c|c|c|}
\hline \multirow{2}{*}{$\begin{array}{l}\text { Variable } \\
\text { Age of mother }\end{array}$} & \multirow{2}{*}{$\begin{array}{l}\text { Sample } \\
\text { Sao Paulo }\end{array}$} & \multicolumn{2}{|c|}{$\begin{array}{c}\text { Median value } \\
\text { (lowest - higest) }\end{array}$} & \multirow{2}{*}{$\begin{array}{c}n \\
37\end{array}$} & \multirow{2}{*}{$\begin{array}{c}\text { Relative } \\
\text { frequency \% } \\
-\end{array}$} & \multirow{2}{*}{$\begin{array}{c}p \\
0.023 *\end{array}$} \\
\hline & & 28 & $(19-44)$ & & & \\
\hline & Barcelona & 34 & $(28-40)$ & 9 & - & \\
\hline & Total & 29 & $(19-44)$ & 46 & - & \\
\hline \multirow[t]{3}{*}{ Age of child } & Sao Paulo & 11 & $(3-33)$ & 37 & - & $0.027^{*}$ \\
\hline & Barcelona & 15 & $(7-32)$ & 9 & - & \\
\hline & Total & 11.5 & $(3-33)$ & 46 & - & \\
\hline \multirow[t]{3}{*}{ Schooling of mother } & Sao Paulo & 11 & $(4-18)$ & 37 & - & $0.008^{*}$ \\
\hline & Barcelona & 15 & (11-21) & 9 & - & \\
\hline & Total & 11 & $(4-21)$ & 46 & - & \\
\hline Gender & Sao Paulo & & - & $18 / 19$ & $48.6 / 51.4$ & $0.464^{\star *}$ \\
\hline \multirow[t]{2}{*}{ Female/male(\%) } & Barcelona & & - & $6 / 3$ & $66.7 / 33.3$ & \\
\hline & Total & & - & $24 / 22$ & 100 & \\
\hline
\end{tabular}

*Result from Mann-Whitney's test; **Result from Fisher's test.

Table 2. Spearman's rank correlation among age of child, Pittsburgh Sleep Quality Index (PSQI), Sleep Efficiency (SE), Sleep Subjective Quality (SSQ), Excessive Daytime Sleepiness (EDS), and Beck Depression Inventory (BDI) for each single sample and for the whole total of mothers.

\begin{tabular}{|c|c|c|c|c|c|c|c|}
\hline Sample & Variables & & Age of child & PSQI & SE & SSQ & EDS \\
\hline \multirow[t]{10}{*}{ Sao Paulo } & PSQI & $r$ & 0.114 & & & & \\
\hline & & $\mathrm{p}$ & 0.503 & & & & \\
\hline & SE & $r$ & 0.042 & -0.707 & & & \\
\hline & & $\mathrm{p}$ & 0.806 & $<0.001$ & & & \\
\hline & SSQ & $r$ & -0.239 & -0.590 & 0.494 & & \\
\hline & & $\mathrm{p}$ & 0.154 & $<0.001$ & 0.002 & & \\
\hline & EDS & $r$ & 0.208 & 0.366 & -0.172 & 0.003 & \\
\hline & & $\mathrm{p}$ & 0.216 & 0.026 & 0.308 & 0.985 & \\
\hline & BDI & $r$ & 0.364 & 0.508 & -0.206 & -0.239 & 0.395 \\
\hline & & $\mathrm{p}$ & 0.027 & 0.001 & 0.220 & 0.155 & 0.016 \\
\hline \multirow[t]{10}{*}{ Barcelona } & PSQI & $r$ & -0.414 & & & & \\
\hline & & $\mathrm{p}$ & 0.269 & & & & \\
\hline & SE & $r$ & 0.782 & -0.545 & & & \\
\hline & & $\mathrm{p}$ & 0.013 & 0.129 & & & \\
\hline & SSQ & $r$ & 0.412 & -0.526 & 0.647 & & \\
\hline & & $\mathrm{p}$ & 0.271 & 0.146 & 0.060 & & \\
\hline & EDS & $r$ & -0.028 & 0.694 & 0.056 & 0.000 & \\
\hline & & $\mathrm{p}$ & 0.944 & 0.038 & 0.886 & $>0.999$ & \\
\hline & BDI & $r$ & -0.118 & 0.254 & -0.021 & 0.413 & 0.389 \\
\hline & & $\mathrm{p}$ & 0.762 & 0.509 & 0.956 & 0.269 & 0.301 \\
\hline \multirow[t]{10}{*}{ Total } & PSQI & $r$ & -0.040 & & & & \\
\hline & & $\mathrm{p}$ & 0.793 & & & & \\
\hline & SE & $r$ & 0.220 & -0.736 & & & \\
\hline & & $\mathrm{p}$ & 0.142 & $>0.001$ & & & \\
\hline & SSQ & $r$ & -0.193 & 0.532 & 0.418 & & \\
\hline & & $\mathrm{p}$ & 0.199 & $>0.001$ & 0.004 & & \\
\hline & EDS & $r$ & 0.118 & 0.424 & -0.169 & 0.040 & \\
\hline & & $\mathrm{p}$ & 0.434 & 0.003 & 0.260 & 0.793 & \\
\hline & BDI & $r$ & 0.254 & 0.506 & -0.246 & -0.128 & 0.392 \\
\hline & & $\mathrm{p}$ & 0.088 & $<0.001$ & 0.100 & 0.398 & 0.007 \\
\hline
\end{tabular}


ical School. The mothers brought the children with complaints of their babies' insomnia. In Barcelona the sample was collected among mothers turning to Clínica del Sueño Estivill who reported complaints of their babies insomnia. As exclusion criteria, mothers whose children bore any organic disorders leading to insomnia or any neurologic disease were excluded.

The mothers' sleep quality was rated by the Pittsburgh Sleep Quality Index (PSQI) ${ }^{7}$, with special focus on Sleep Subjective Quality (SSQ), Sleep Efficiency (SE), and Excessive Daytime Sleepiness (EDS) being rated by means of Beck's Depression Inventory $(\mathrm{BDI})^{8}$. Statistical correlations between data collected in São Paulo and in Barcelona were carried out using Fisher's exact test, Mann-Whitney's and Spearman rank correlation's tests to verify statistical value, with a value of $p<0.05$ adopted as the significance parameter.

The Research Ethics Committee approved the project at Hospital das Clinicas, University of São Paulo Medical School. All mothers agreed to participate in the study and signed the term of free and informed consent.

\section{RESULTS}

The whole sample was composed by mothers of 24 girls and 22 boys distributed between the two towns as shows at Table 1. No significant gender difference was found between the samples. Both the ages of Barcelona children and mothers were significantly higher than those of São Paulo and as for regular school education Barcelona mother displayed significantly longer years of schooling.

In the grand total, $91.30 \%$ of mothers reported poor sleep by PSQI standards (São Paulo 91.89\%, Barcelona $88.88 \%$ ); $86.96 \%$ of all mothers showed low SE (São Paulo $89.19 \%$, Barcelona $77.78 \%$ ). EDS was found in $58.70 \%$ of the whole sample (São Paulo 62.16\%, Barcelona 44.44\%). Regarding the presence of signs and symptoms of depression, $69.57 \%$ of all mothers in the sample showed them (São Paulo 70\%, Barcelona 66.67\%).

Table 2 shows that direct statistically significant correlation between São Paulo mothers PSQI and BDI was found and also between the child's age and BDI. PSQI had statistically significant correlation with SSQ and EDS; BDI with EDS; SE with SSQ. Between PSQI and SE the correlation was reverse, since as PSQI higher scores imply poorer sleep as sleep efficiency worsens. Concerning Barcelona mothers, the direct correlation observed between SE and the children' age and between PSQI and EDS was statistically significant. In the total number of subjects observed, the result was similar to that found among São Paulo mothers.

\section{DISCUSSION}

Barcelona mothers turned out to be significantly older than São Paulo mothers and held longer schooling years as well. It must be taken into account that in São Paulo the mothers were evaluated in a state-run institution while in Barcelona from a private institution. Also, the level of schooling years in Barcelona general population is higher than that of São Paulo.

From data concerning São Paulo mothers, it stands out that the poor sleep detected by PSQI scores was correlated to the presence of depressive signs and symptoms. Also, that these mothers were aware (SSQ) of what was making them suffer, their sleep impairment, which was also seen by their SE decrease and the presence of EDS. Besides, it was also found that the older the child, the higher their mothers signs and symptoms of depression. Therefore we suppose the longer the time which the mother is deprived from sleep - due to their child's insomnia - the more intense their signs and symptoms of depression. Few studies associate poor mother's early parenting practices with maternal depression symptoms mainly in the first months of life $e^{9,10}$.

EDS among mothers in São Paulo and in the total sample were correlated to the presence of depression signs and symptoms, only to confirm clinical complaints.

The present study concluded that mothers of insomniac babies showed severe impairment of sleep quality. The mothers' poor sleep was related to mood changes with symptoms of depression presenting similar results in São Paulo and Barcelona.

\section{REFERENCES}

1. Davis KF, Parker KP, Montgomery Gl. Sleep in infants and young children: Part 1: Normal sleep. J Pediatr Health Care 2004;18:65-71.

2. Armstrong KL, Quinn RA, Dadds MR. The sleep patterns of normal children. Med J Aust 1994;161:200-206.

3. ICSD - International Classification of Sleep Disorders. Diagnostic and coding manual. Rochester: American Sleep Disorders Association, 2005.

4. Mesquita G, Reimão R. Nightly use of computer by adolescents: its effects on quality of sleep. Arq Neuropsiquiatr 2007;65:428-432.

5. Neves SN, Reimão R. Sleep disturbances in 50 children with attentiondeficit hyperactivity disorder. Arq Neuropsiquiatr 2007;65:228-233.

6. Estivill E. Insomnio infantil por hábitos incorrectos. Rev Neurol 2000; 30:188-191.

7. Buysse DJ, Reynolds CF, Monk TH, Berman SF, Kupfer DJ. The Pittsburgh Sleep Quality Index: a new instrument for psychiatric practice and research. Psychiatr Res 1989;28:193-213.

8. Gorenstein C, Andrade L. Inventário de depressão de Beck: propriedades psicométricas da versão em português. Rev Psicol Clin 1998;25: 245-250.

9. Dennis CL, Ross L. Relationship among infant sleep patterns, maternal fatigue, and development of depressive symptomatology. Birth 2005;32:187-193.

10. McLean KT, Minkovitz CS, Strobino DM, Marks E, Hou W. Maternal depressive symptoms at 2 to 4 months post partum and early parenting practices. Arch Pediatr Adolesc Med 2006;160:279-284. 